\title{
Morphometric Characteristic between Diploid and Spontaneous Triploid Carp in Korea
}

\author{
Sang Gu Lim ${ }^{1}$, Hyeng Keun Han ${ }^{2}$, In Bon Goo ${ }^{3}$, Hyun Woo Gil ${ }^{4}$, Tae Ho Lee ${ }^{5}$ and ${ }^{\dagger}$ In-Seok Park ${ }^{4}$ \\ ${ }^{I}$ Future Aquaculture Research Center, National Institute of Fisheries Science (NIFS), Jeju 63610, Korea \\ ${ }^{2}$ Tidal Flat Research Center, NIFS, Incheon 22383, Korea \\ ${ }^{3}$ Inland Aquaculture Research Center, NIFS, Changwon 51688, Korea \\ ${ }^{4}$ Division of Marine Bioscience, College of Ocean Science and Technology, \\ Korea Maritime and Ocean University, Busan 49112, Korea \\ ${ }^{5}$ Department of Marine Bio-materials and Aquaculture, College of Fisheries Science, \\ Pukyong National University, Busan 48513, Korea
}

\begin{abstract}
We used flowcytometry to ploidy verification after that investigate difference between diploid and spontaneous triploid through the truss dimension and classical dimension at crucian carp, Carassius auratus, crucian carp C. cuvieri and common carp, Cyprinus carpio collected from Hangang river, Hantangang river, Imjingang river, Geumgang river, Yeongsangang river and Nakdonggang river, Korea. There were significant differences among the three species for the truss dimensions anterior origin of dorsal fin (2) $\times$ anterior origin of anal fin (5), $2 \times$ anterior origin of pelvic fin (6), $2 \times$ origin of pectoral fin (7), posterior origin of dorsal fin $(3) \times 5,3 \times 6$, and $3 \times 7(P<0.05)$. There were no significant differences among the three species in the truss dimensions dorsal fin length $(2 \times 9)$ and eye diameter $(\mathrm{ED})(P>0.05)$. On the other hand, there were no significant differences in the several classical dimensions of each species $(P>0.05)$. Three classical dimensions, most anterior extension of the head $(1) \times 2,1 \times 6$ and $2 \times$ most posterior scale in lateral line (4) did not differ between the $C$. auratus diploid and spontaneous triploid $(P>0.05)$. Two classical dimensions, $1 \times 6$ and longest length between most anterior extension of the head and gill cover $(1 \times 8)$ did not differ between the $C$. cuvieri diploid and spontaneous triploid $(P>0.05)$. One classical dimensions, $1 \times 2$ did not differ between the common carp diploid and spontaneous triploid $(P>0.05)$. There were significant differences in the each diploid and triploid species $(P<0.05)$. These results suggest that the classification of each species and classification between diploid and spontaneous triploid morphometrical parameters used in this study are useful indices of morphometrical status in the each species from major river of Korea.
\end{abstract}

Key words : Carassius auratus, C. cuvieri, Cyprinus carpio, Diploid, Spontaneous triploid, Morphometrical characters

\section{INTRODUCTION}

A morphometrical difference is understood by a general body shape or anatomical shape at population between species (Strauss \& Bond, 1990). Morphometric characters, as measured trait, was among body characters of fish, it was measured at fish body. Although morphometrical characters oneself by variance to have been caused environmentally can change, the body shape of fish is completely determined by genetic factors (Currens et al., 1989; Park et al., 2001b).

The morphometrical study may be used basically in the

\footnotetext{
Manuscript received February 15, 2017, Received in revised form February 17, 2017, Accepted February 19, 2017

${ }^{\dagger}$ Corresponding Author : In-Seok Park, Division of Marine Bioscience, College of Ocean Science and Technology, Korea Maritime and Ocean University, Busan 49112, Korea. Tel: +82-51-410-4321, Fax: +82-51-404-4750, E-mail: ispark@kmou.ac.kr

This is an Open Access article distributed under the terms of the Creative Commons Attribution Non-Commercial License (http:// creativecommons.org/licenses/by-nc/3.0) which permits unrestricted non-commercial use, distribution, and reproduction in any medium, provided the original work is properly cited.
} 
three study sides. First, identification of the species and gender (Park et al., 2001a), along with confirm species such as uncertain hybrid (Strauss, 1986; Park et al., 2003); Second, study out the morphometrical changes of population and species (Strauss, 1985; Lee \& Kim, 1990; Park et al., 2001b and 2015; Goo et al., 2015); and third, biological systematic identification of association and classification.

Both truss and classical dimensions are used to describe fish body shape (Strauss \& Bookstein, 1982). Truss dimensions consist of a systematically arranged set of distances that are measured between a set of preselected anatomical landmarks. These landmarks are identified based on local morphological features, and they are chosen to divide the body into functional units (Strauss \& Bond, 1990). Truss dimensions, which include components of body depth and length along the longitudinal axis, have theoretical advantages over classical morphometric characteristics for discriminating among groups (Park et al., 2007 and 2015; Goo et al., 2015).

Crucian carp, Carassius auratus, crucian carp, C. cuvieri and common carp, Cyprinus carpio were wide-spread freshwater species in Korea (Kim, 1997). Under the natural ecosystem, crucian carp is widely distributed in the entire lakes, marshes and rivers in the Korean Peninsula as well as in the several areas in Japan, China, Taiwan, Silberia and the European Continent. In particular, one of species of crucian carp, Carassius auratus is an economically important aquacultural species belonging to the family Cyprinidae. The common name, crucian carp in Korea was identified, C. auratus, by means of morphology and electrophoretic analysis (Nam et al., 1989). The genus Carassius can be categorizes as a species complex because morphological differences resulting from environmental influences (Nam et al., 1989). The fresh water crucian carp, C. cuvieri was introduced to Korea from Japan in 1970s and intentionally released to rivers and reservoirs as food resources. Surpassing other fish species in fertility and adaptation against environmental change, this exotic species has threatened the survival of indigenous fish species (Song et al., 2007).

The common carp is a widespread freshwater fish of eutrophic waters in lakes and large rivers in Europe and Asia. Wild common carp are typically slimmer than domesticated forms, with body length about four times body height, red flesh, and a forward-protruding mouth. Their average growth rate by weight is about half the growth rate of domesticated carp (Chun et al., 1983).

These species were found triploid natural condition. Recently, Lim et al. (2015) suggest there are spontaneous triploid these three species. This study purpose was investigation difference between diploid and spontaneous triploid for each of C. auratus, C. cuvieri and common carp.

\section{MATERIALS AND METHODS}

In 2012, specimens of the crucian carp, Carassius auratus, crucian carp, C. cuvieri and common carp, Cyprinus carpio were netted in the Hangang river, Hantangang river, Imjingang river, Geumgang river, Yeongsangang river and Nakdonggang river, Korea during the June (Fig. 1). For morphometrical measurement, fifty specimens for each species were fixed in $10 \%$ neutral formalin solution (100 $\mathrm{mL}$ formalin, $6.5 \mathrm{~g} \mathrm{Na}_{2} \mathrm{HPO}_{4} \cdot 12 \mathrm{H}_{2} \mathrm{O}, 4.5 \mathrm{~g} \mathrm{KH}_{2} \mathrm{PO}_{4}, 900$ $\mathrm{mL}$ distilled water). Before fixed in $10 \%$ neutral formalin solution, ventral fins were collected from each fresh fishes, and fins fixed $70 \%$ ethanol $(700 \mathrm{~mL}$ ethanol, $300 \mathrm{~mL}$ distilled water) for ploidy verification.

Ploidy verification was using flowcytometry according to Lim et al. (2015). The samples were analysed using flowcytometry measurement. For flowcytometric analysis, tissue of ventral fin homogenized and filtered using $30 \mu \mathrm{m}$ filter, after that centrifugation (Centrifuge Micro 17R, Hanil Science Industrial Co., Ltd, Incheon, Korea; 


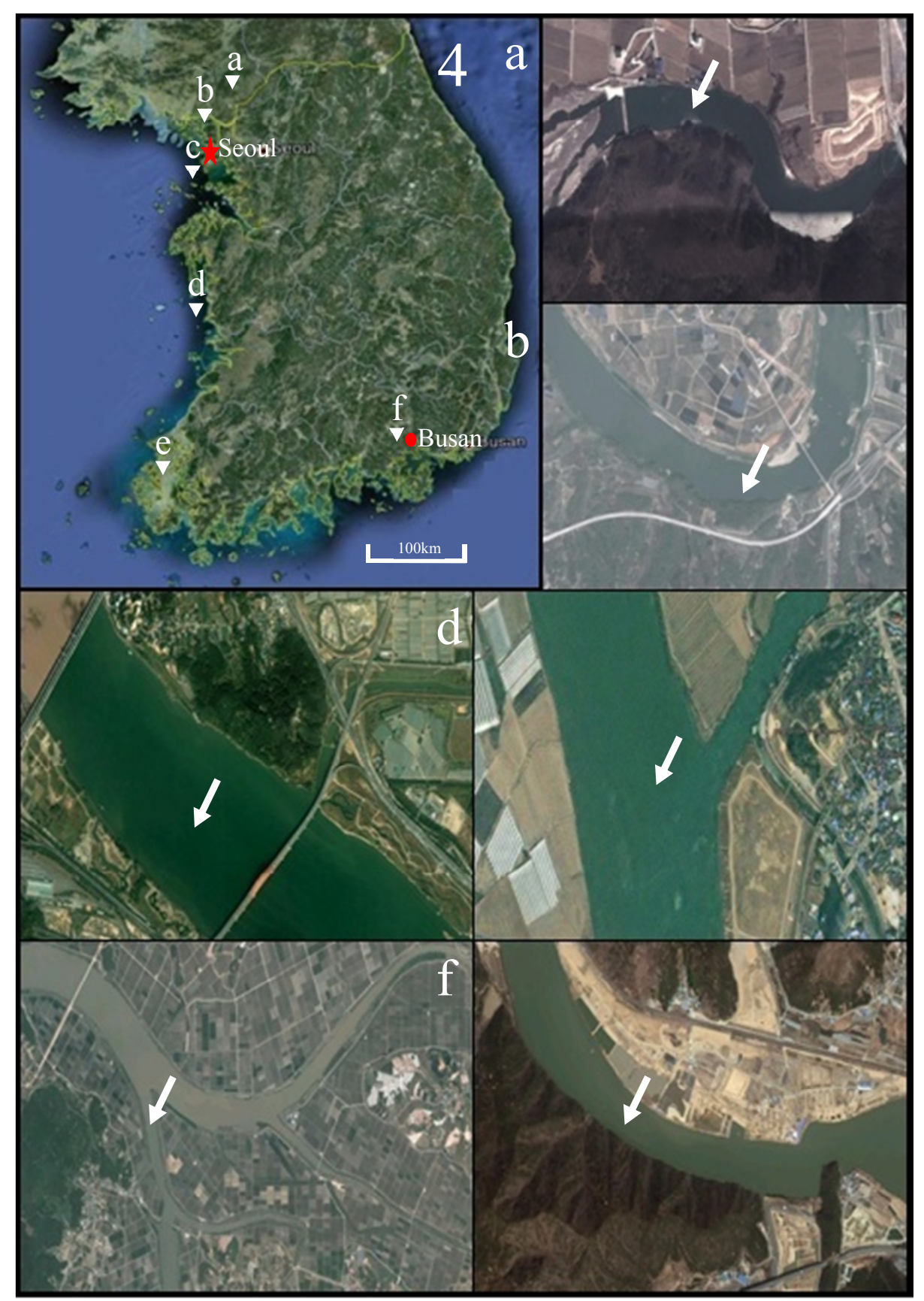

Fig. 1. Sampling location of crucian carp, Carassius auratus, crucian carp, C. cuvieri and common carp, Cyprinus carpio on Korean map and satellite map. Hantangang river (a): Gomun-ri, Yeoncheon-eup, Yeoncheon-gun, Gyeonggi-do, Korea (38 03' 41.29" N, $127^{\circ} 07^{\prime}$ 20.80" E); Imjingang river (b): Wondang-ri, Jangnam myeon,

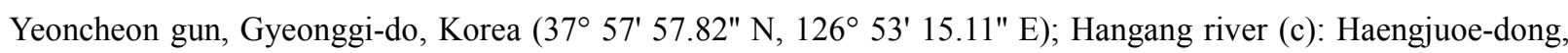
Deokyang-gu, Goyang-si, Gyeonggi-do, Korea (37 35' 31.13" N, $126^{\circ} 49^{\prime} 09.56^{\prime \prime}$ E); Geumgang river (d): Seochang-ri, Ganggyeong-eup, Nonsan-si, Chungcheongnam-do, Korea ( $\left.36^{\circ} 09^{\prime} 44.21^{\prime \prime} \mathrm{N}, 127^{\circ} 00^{\prime} 31.86^{\prime \prime} \mathrm{E}\right)$; Youngsan river (e): Sinhak-ri, Sijong-myeon, Yeongam-gun, Jeollanam-do, Korea (34 48 $35.44^{\prime \prime}$ N, $126^{\circ} 36^{\prime}$ 17.67" E); Nakdonggang river (f): Doyo-ri, Saengnim-myeon, Gimhae-si, Gyeongsangnam-do, Korea $\left(35^{\circ} 21^{\prime}\right.$ $55.21^{\prime \prime} \mathrm{N}, 128^{\circ} 53^{\prime} 13.39^{\prime \prime}$ E)(After Lim et al., 2015). 
1,000 rpm, $10 \mathrm{~min}$ ). And then, Removed supernatant liquid and added $0.5 \mathrm{~mL}$ CyStain DNA 2 step nuclei extraction buffer (CyStain DNA 2 step high resolution DNA staining kit, Partec, Germany) and 2 mL CyStain DNA 2 step staining buffer (CyStain DNA 2 step high resolution DNA staining kit, Partec, Germany).

Both the truss dimensions and classical dimensions are used to describe the external morphology of fish (Strauss \& Bookstein, 1982). Digital Vernier calipers (CD-20CP; Mitutoyo, Japan) were used for all length measurements, in units of $0.1 \mathrm{~mm}$. The external morphemetric traits, shown in Table 1 and Fig. 2, were measured in terms of truss dimensions and classical dimensions. Each of the morphometric trait measurements obtained for the fishes was arc sin square root transformed about the portion of the standard length $(L s)$, after which the relative ratios were determined. All of the measurements were standardized by dividing by the $L$ s to compare the measurements and were tested by the student's $t$-test from the SPSS statistics package (SPSS 9.0, SPSS Inc. Chicago, IL, USA).

\section{RESULTS AND DISCUSSION}

In this experiment, used the crucian carp, Carassius auratus average standard length $(L s)$ of the diploid was $20.8 \pm 6.00 \mathrm{~cm}$, and the spontaneous triploid was $21.5 \pm 4.90$ $\mathrm{cm}$. The crucian carp, $C$. cuvieri average $L$ s of the diploid was $26.2 \pm 4.84 \mathrm{~cm}$, and the spontaneous triploid was $29.6 \pm 6.42 \mathrm{~cm}$. The common carp, Cyprinus carpio average $L \mathrm{~s}$ of the diploid was $39.3 \pm 5.56 \mathrm{~cm}$, and the spontaneous triploid was $41.7 \pm 5.76 \mathrm{~cm}$.

Through the truss dimension and classical dimension at

Table 1. Dimension of body shape used in this study

\begin{tabular}{lc}
\hline \hline & Dimensions \\
\hline Standard length & $L$ S \\
Eye diameter & ED \\
Most anterior extension of the head $\times$ anterior origin of dorsal fin & $1 \times 2$ \\
Most anterior extension of the head $\times$ posterior origin of dorsal fin & $1 \times 5$ \\
Most anterior extension of the head $\times$ anterior origin of anal fin & $1 \times 6$ \\
Most anterior extension of the head $\times$ anterior origin of pelvic fin & $1 \times 8$ \\
Longest length between most anterior extension of the head and gill cover & $2 \times 4$ \\
Anterior origin of dorsal fin $\times$ most posterior scale in lateral line & \\
\hline
\end{tabular}

\section{Truss dimension}

Anterior origin of dorsal fin $\times$ anterior origin of anal fin $2 \times 5$

Anterior origin of dorsal fin $\times$ anterior origin of pelvic fin $2 \times 6$

$\begin{array}{lll}\text { Anterior origin of dorsal fin } \times \text { origin of pectoral fin } & 2 \times 7\end{array}$

$\begin{array}{ll}\text { Dorsal fin length } & 2 \times 9\end{array}$

Posterior origin of dorsal fin $\times$ anterior origin of anal fin $3 \times 5$

Posterior origin of dorsal fin $\times$ anterior origin of pelvic fin $3 \times 6$

$\begin{array}{ll}\text { Posterior origin of dorsal fin } \times \text { origin of pectoral fin } & 3 \times 7\end{array}$ 


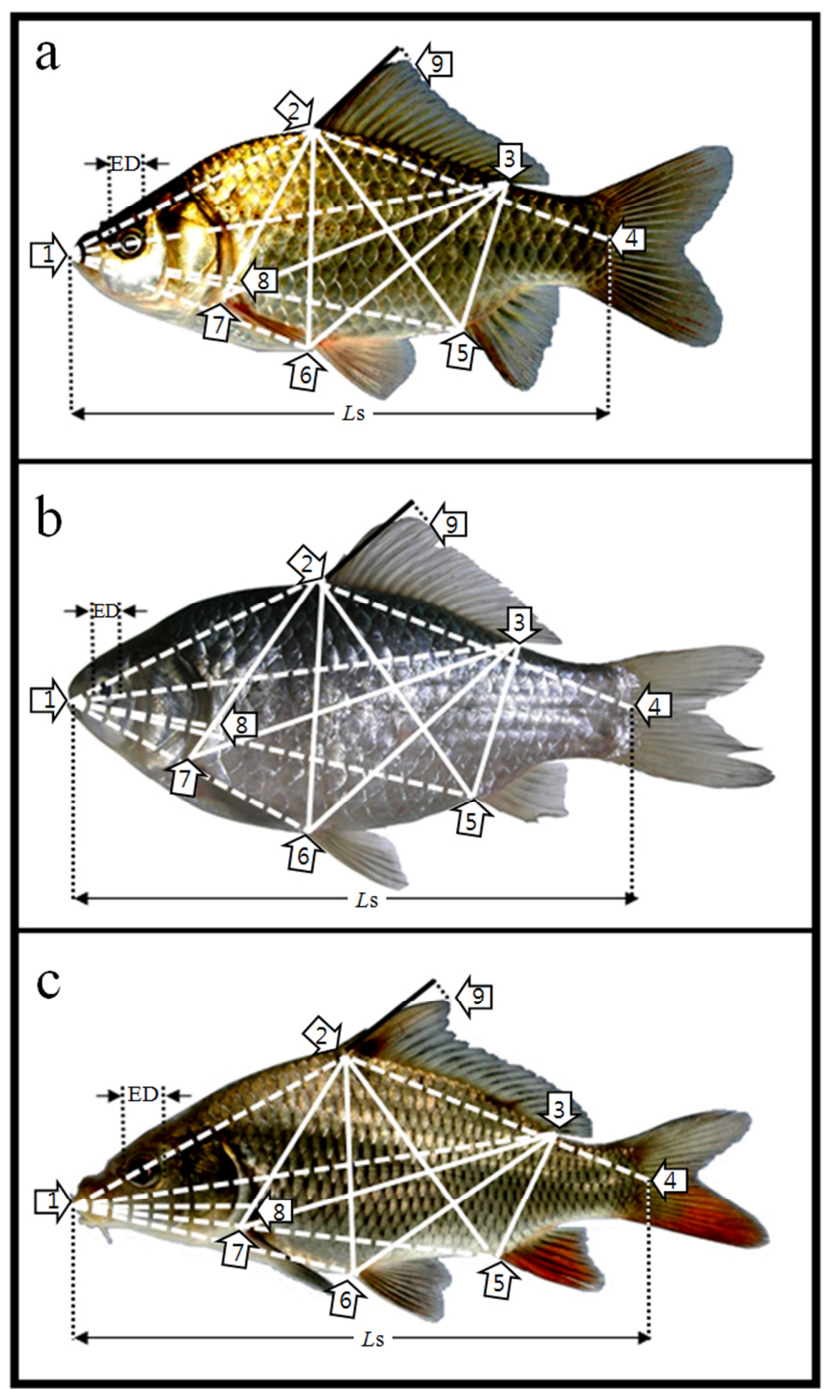

Fig. 2. Morphometric measurements among each landmarks of (a) crucian carp, Carassius auratus, (b) crucian carp, $C$. cuvieri and (c) common carp, Cyprinus carpio used in this study. For each landmark, see Table 1. ED, eye diameter; $L s$, standard lenth; — $\longrightarrow$ truss dimension; - - - classical dimension.

C. auratus, C. cuvieri and common carp, each measurement traits and compared them with each other and the results are shown in Table 2. There were significant differences among the three species for the truss dimensions $2 \times 5$, $2 \times 6,2 \times 7,3 \times 5,3 \times 6$ and $3 \times 7(P<0.05)$. There were no significant differences in the truss dimensions $2 \times 9$ and ED $(P>0.05)$. On the other hand, there were no significant differences in the several classical dimensions of each species $(P>0.05)$. Three classical dimensions, $1 \times 2,1 \times 6$ and $2 \times 4$ did not differ between the $C$. auratus diploid and spontaneous triploid $(P>0.05)$. Two classical dimensions, $1 \times 6$ and $1 \times 8$ did not differ between the C. cuvieri diploid and spontaneous triploid $(P>0.05)$. One classical dimensions, $1 \times 2$ did not differ between the common carp diploid and spontaneous triploid $(P>0.05)$.

The truss dimensions, in particular, are the primary units of classification of the external anatomical markers normally assessed in fish (Strauss \& Bond, 1990). The truss dimensions are length measurements that refer to the ratio between the width of the fish's body and the axis of the fish's length. Theoretically, the truss dimensions are a better measurement of the fish's shape than the classical dimensions (Strauss \& Bookstein, 1982; Currens et al., 1989). Truss dimensions in this study shown more significant difference items then classical dimensions.

Table 3 shown morphometric measurements and results of diploid and triploid spontaneous generation on $C$. $a u$ ratus, C. cuvieri and common carp. There were significant differences in the each diploid and triploid species $(P<$ 0.05). Relative to the diploid C. auratus, for the diploid $C$. cuvieri the values of $1 \times 3$ and $1 \times 5$ more greater but those of $2 \times 4$ smaller, while for the diploid common carp the values of $1 \times 2,1 \times 6,1 \times 8$ and $2 \times 4$ more greater in the classical dimensions $(P<0.05)$. Relative to the triploid $C$. $a u$ ratus, for the triploid $C$. cuvieri the values of $1 \times 2,1 \times 3$, and $1 \times 5$ more greater but those of $2 \times 4$ smaller, while for the triploid common carp the values of $1 \times 2,1 \times 6,1 \times 8$, and $2 \times 4$ more greater in the classical dimensions $(P<0.05)$. Significant differences were also found in the truss dimensions $(P<0.05)$. Relative to the diploid C. auratus, for the diploid $C$. cuvieri the values of $3 \times 7$ more greater but those of $2 \times 6$ and $3 \times 5$ smaller, while for the diploid common carp the values of $2 \times 5,2 \times 6,2 \times 7,3 \times 5$ and $3 \times 6$ more greater in the truss dimensions $(P<0.05)$. Relative to the triploid C. auratus, for the triploid C. cuvieri the values of $2 \times 5$, 
SG Lim, HK Han, IB Goo, HW Gil, TH Lee, I-S Park

Table 2. Morphometric measurements and results of $t$-test for significances of diploid and triploid spontaneous generation on crucian carp, Carassius auratus, crucian carp, $C$. cuvieri and common carp, Cyprinus carpio*

\begin{tabular}{|c|c|c|c|c|c|c|c|c|c|}
\hline \multirow{2}{*}{$\begin{array}{l}\text { Morphometric } \\
\text { measurement }\end{array}$} & \multicolumn{3}{|c|}{ Carassius auratus } & \multicolumn{3}{|c|}{ C. cuvieri } & \multicolumn{3}{|c|}{ Cyprinus carpio } \\
\hline & Diploid & Triploid & $t$-test & Diploid & Triploid & $t$-test & Diploid & Triploid & $t$-test \\
\hline$L s(\mathrm{~cm})$ & $20.8 \pm 6.00$ & $21.5 \pm 4.90$ & $\dagger$ & $26.2 \pm 4.84$ & $29.6 \pm 6.42$ & $\dagger$ & $39.3 \pm 5.56$ & $41.7 \pm 5.76$ & $\dagger$ \\
\hline \multirow[t]{2}{*}{$\mathrm{ED} / L s$} & $5.3 \pm 1.17$ & $5.2 \pm 1.03$ & NS & $4.9 \pm 0.52$ & $5.3 \pm 0.80$ & NS & $3.5 \pm 0.47$ & $3.1 \pm 0.43$ & NS \\
\hline & \multicolumn{9}{|c|}{ Classical dimension } \\
\hline $1 \times 2 / L s$ & $49.3 \pm 5.14$ & $49.1 \pm 2.67$ & NS & $48.1 \pm 3.61$ & $44.3 \pm 5.21$ & $\dagger$ & $43.1 \pm 7.87$ & $43.9 \pm 6.34$ & NS \\
\hline $1 \times 3 / L s$ & $57.6 \pm 7.24$ & $56.1 \pm 6.41$ & $\dagger$ & $39.3 \pm 5.56$ & $43.9 \pm 5.56$ & $\dagger$ & $58.2 \pm 8.12$ & $57.3 \pm 7.24$ & $\dagger$ \\
\hline $1 \times 5 / L s$ & $56.8 \pm 6.22$ & $55.5 \pm 8.04$ & $\dagger$ & $39.3 \pm 5.56$ & $39.3 \pm 5.56$ & $\dagger$ & $57.1 \pm 7.88$ & $55.8 \pm 8.61$ & $\dagger$ \\
\hline $1 \times 6 / L s$ & $45.9 \pm 3.69$ & $45.3 \pm 2.67$ & NS & $44.3 \pm 7.18$ & $43.9 \pm 4.81$ & NS & $39.7 \pm 6.08$ & $41.3 \pm 7.88$ & $\dagger$ \\
\hline $1 \times 8 / L s$ & $27.1 \pm 2.74$ & $28.0 \pm 2.45$ & $\dagger$ & $28.0 \pm 2.61$ & $28.7 \pm 6.82$ & NS & $25.6 \pm 6.35$ & $23.5 \pm 8.14$ & $\dagger$ \\
\hline \multirow[t]{2}{*}{$2 \times 4 / L s$} & $59.5 \pm 3.43$ & $59.6 \pm 2.14$ & NS & $61.4 \pm 5.38$ & $62.8 \pm 6.08$ & $\dagger$ & $56.7 \pm 9.78$ & $55.4 \pm 9.06$ & $\dagger$ \\
\hline & \multicolumn{9}{|c|}{ Truss dimension } \\
\hline $2 \times 5 / L s$ & $44.6 \pm 3.22$ & $43.7 \pm 1.82$ & $\dagger$ & $45.6 \pm 4.59$ & $47.3 \pm 4.38$ & $\dagger$ & $40.6 \pm 4.34$ & $39.1 \pm 7.42$ & $\dagger$ \\
\hline $2 \times 6 / L s$ & $35.6 \pm 2.23$ & $34.5 \pm 1.64$ & $\dagger$ & $38.8 \pm 3.40$ & $41.2 \pm 3.51$ & $\dagger$ & $26.0 \pm 3.05$ & $25.2 \pm 6.88$ & $\dagger$ \\
\hline $2 \times 7 / L s$ & $35.5 \pm 1.85$ & $33.7 \pm 1.85$ & $\dagger$ & $36.5 \pm 3.70$ & $35.8 \pm 6.63$ & $\dagger$ & $28.7 \pm 2.12$ & $27.3 \pm 8.14$ & $\dagger$ \\
\hline $2 \times 9 / L s$ & $13.9 \pm 2.99$ & $14.4 \pm 2.11$ & NS & $13.4 \pm 2.33$ & $13.2 \pm 1.28$ & NS & $14.1 \pm 9.09$ & $13.9 \pm 5.50$ & NS \\
\hline $3 \times 5 / L s$ & $23.7 \pm 3.66$ & $24.6 \pm 1.47$ & $\dagger$ & $25.8 \pm 4.40$ & $27.4 \pm 4.04$ & $\dagger$ & $19.1 \pm 2.75$ & $18.5 \pm 6.77$ & $\dagger$ \\
\hline $3 \times 6 / L s$ & $44.7 \pm 3.77$ & $43.0 \pm 3.04$ & $\dagger$ & $44.0 \pm 4.58$ & $49.0 \pm 5.56$ & $\dagger$ & $39.8 \pm 2.90$ & $41.5 \pm 7.31$ & $\dagger$ \\
\hline $3 \times 7 / L s$ & $57.4 \pm 5.12$ & $55.5 \pm 2.76$ & $\dagger$ & $55.3 \pm 5.36$ & $57.8 \pm 6.32$ & $\dagger$ & $56.9 \pm 9.34$ & $59.7 \pm 8.11$ & $\dagger$ \\
\hline
\end{tabular}

${ }^{*}$ Data of each experimental group were analyzed using $t$-test on data transformed to the arcsine of the square root. NS: no significant; $\uparrow: 0.05$. Refer to the landmarks in Fig. 1 and Table 1 for the dimension numbers in Table 2.

$2 \times 6,2 \times 7,3 \times 5,3 \times 6$, and $3 \times 7$ more smaller, while for the triploid common carp the values of $2 \times 5,2 \times 6,2 \times 7,3 \times 5$, and $3 \times 6$ more greater but those of $3 \times 7$ smaller in the truss dimensions $(P<0.05)$. The truss dimension $2 \times 9$, did not differ significantly among the three species $(P>0.05)$. Especially, linked to body height, truss dimension $2 \times 6$ more greater $C$. cuvieri than $C$. auratus. It means $C$. cuvieri has higher body height than $C$. auratus, and body shape of $C$. cuvieri was character (Kim, 1997). Those of 2 species $C$. cuvieri and C. auratus have certainly different body shape at most anterior extension of the head to anterior origin of dorsal fin observing naked eyes. But, truss dimension $1 \times 2$ about this region not different between 2 species. With regard to morphometrical measurement, will be needed another method about body shape.

Spontaneous triploid of C. auratus, C. cuvieri and common carp were reported by Lim et al. (2015). As result of Lim et al. (2015), C. auratus, C. cuvieri and common carp, triploid has 1,5 times DNA contents compared with diploid. Whereas, morphometric characteristic of diploid and triploid among 3 species was small difference, not certainly larger 1.5 times than diploid in this study. As mentioned Benfey (1999), triploid cell nuclei contain, by definition, 50\% more DNA than diploid cell nuclei. Nuclear volume is increased in triploids to accommodate this extra genetic material. A corresponding increase in cellular 
Table 3. Morphometric measurements and results of diploid and triploid spontaneous generation on crucian carp, Carassius auratus, crucian carp, $C$. cuvieri and common carp, Cyprinus carpio*

\begin{tabular}{|c|c|c|c|c|c|c|}
\hline $\begin{array}{l}\text { Morphometric } \\
\text { measurement }\end{array}$ & $\begin{array}{c}\text { Carassius } \\
\text { auratus }\end{array}$ & C. cuvieri & $\begin{array}{c}\text { Cyprinus } \\
\text { carpio }\end{array}$ & $\begin{array}{c}\text { Carassius } \\
\text { auratus }\end{array}$ & C. cuvieri & $\begin{array}{c}\text { Cyprinus } \\
\text { carpio }\end{array}$ \\
\hline$L \mathrm{~s}(\mathrm{~cm})$ & $20.8 \pm 6.00^{\mathrm{a}}$ & $26.2 \pm 4.84^{\mathrm{b}}$ & $39.3 \pm 5.56^{\mathrm{c}}$ & $21.5 \pm 4.90^{\mathrm{a}}$ & $29.6 \pm 6.42^{b}$ & $41.7 \pm 5.76^{\mathrm{c}}$ \\
\hline $\mathrm{ED} / L \mathrm{~s}$ & $5.3 \pm 1.17^{\mathrm{b}}$ & $4.9 \pm 0.52^{\mathrm{ab}}$ & $3.5 \pm 0.47^{\mathrm{a}}$ & $5.2 \pm 1.03^{\mathrm{b}}$ & $5.3 \pm 0.80^{b}$ & $3.1 \pm 0.43^{\mathrm{a}}$ \\
\hline & \multicolumn{6}{|c|}{ Classical dimension } \\
\hline $1 \times 2 / L s$ & $49.3 \pm 5.14^{\mathrm{b}}$ & $48.1 \pm 3.61^{b}$ & $43.1 \pm 7.87^{\mathrm{a}}$ & $49.1 \pm 2.67^{\mathrm{b}}$ & $44.3 \pm 5.21^{\mathrm{a}}$ & $43.9 \pm 6.34^{\mathrm{a}}$ \\
\hline $1 \times 3 / L s$ & $57.6 \pm 7.24^{b}$ & $39.3 \pm 5.56^{\mathrm{a}}$ & $58.2 \pm 8.12^{\mathrm{b}}$ & $56.1 \pm 6.41^{b}$ & $43.9 \pm 5.56^{\mathrm{a}}$ & $57.3 \pm 7.24^{b}$ \\
\hline $1 \times 5 / L s$ & $56.8 \pm 6.22^{b}$ & $39.3 \pm 5.56^{\mathrm{a}}$ & $57.1 \pm 7.88^{\mathrm{b}}$ & $55.5 \pm 8.04^{\mathrm{b}}$ & $39.3 \pm 5.56^{\mathrm{a}}$ & $55.8 \pm 8.61^{b}$ \\
\hline $1 \times 6 / L s$ & $45.9 \pm 3.69^{b}$ & $44.3 \pm 7.18^{b}$ & $39.7 \pm 6.08^{\mathrm{a}}$ & $45.3 \pm 2.67^{\mathrm{b}}$ & $43.9 \pm 4.81^{\mathrm{b}}$ & $41.3 \pm 7.88^{\mathrm{a}}$ \\
\hline $1 \times 8 / L s$ & $27.1 \pm 2.74^{b}$ & $28.0 \pm 2.61^{b}$ & $25.6 \pm 6.35^{\mathrm{a}}$ & $28.0 \pm 2.45^{\mathrm{b}}$ & $28.7 \pm 6.82^{b}$ & $23.5 \pm 8.14^{\mathrm{a}}$ \\
\hline $2 \times 4 / L s$ & $59.5 \pm 3.43^{b}$ & $61.4 \pm 5.38^{\mathrm{c}}$ & $56.7 \pm 9.78^{\mathrm{a}}$ & $59.6 \pm 2.14^{\mathrm{b}}$ & $62.8 \pm 6.08^{c}$ & $55.4 \pm 9.06^{\mathrm{a}}$ \\
\hline & \multicolumn{6}{|c|}{ Truss dimension } \\
\hline $2 \times 5 / L s$ & $44.6 \pm 3.22^{b}$ & $45.6 \pm 4.59^{b}$ & $40.6 \pm 4.34^{\mathrm{a}}$ & $43.7 \pm 1.82^{b}$ & $47.3 \pm 4.38^{\mathrm{c}}$ & $39.1 \pm 7.42^{\mathrm{a}}$ \\
\hline $2 \times 6 / L s$ & $35.6 \pm 2.23^{\mathrm{b}}$ & $38.8 \pm 3.40^{\mathrm{c}}$ & $26.0 \pm 3.05^{\mathrm{a}}$ & $34.5 \pm 1.64^{\mathrm{b}}$ & $41.2 \pm 3.51^{\mathrm{c}}$ & $25.2 \pm 6.88^{\mathrm{a}}$ \\
\hline $2 \times 7 / L s$ & $35.5 \pm 1.85^{\mathrm{b}}$ & $36.5 \pm 3.70^{b}$ & $28.7 \pm 2.12^{\mathrm{a}}$ & $33.7 \pm 1.85^{\mathrm{b}}$ & $35.8 \pm 6.63^{\mathrm{c}}$ & $27.3 \pm 8.14^{\mathrm{a}}$ \\
\hline $2 \times 9 / L \mathrm{~s}$ & $13.9 \pm 2.99^{\mathrm{a}}$ & $13.4 \pm 2.33^{\mathrm{a}}$ & $14.1 \pm 9.09^{\mathrm{a}}$ & $14.4 \pm 2.11^{\mathrm{a}}$ & $13.2 \pm 1.28^{\mathrm{a}}$ & $13.9 \pm 5.50^{\mathrm{a}}$ \\
\hline $3 \times 5 / L s$ & $23.7 \pm 3.66^{\mathrm{b}}$ & $25.8 \pm 4.40^{\mathrm{c}}$ & $19.1 \pm 2.75^{\mathrm{a}}$ & $24.6 \pm 1.47^{\mathrm{b}}$ & $27.4 \pm 4.04^{\mathrm{c}}$ & $18.5 \pm 6.77^{\mathrm{a}}$ \\
\hline $3 \times 6 / L s$ & $44.7 \pm 3.77^{b}$ & $44.0 \pm 4.58^{b}$ & $39.8 \pm 2.90^{\mathrm{a}}$ & $43.0 \pm 3.04^{\mathrm{b}}$ & $49.0 \pm 5.56^{\mathrm{c}}$ & $41.5 \pm 7.31^{\mathrm{a}}$ \\
\hline $3 \times 7 / L s$ & $57.4 \pm 5.12^{b}$ & $55.3 \pm 5.36^{\mathrm{a}}$ & $56.9 \pm 9.34^{\mathrm{ab}}$ & $55.5 \pm 2.76^{\mathrm{a}}$ & $57.8 \pm 6.32^{b}$ & $59.7 \pm 8.11^{\mathrm{c}}$ \\
\hline
\end{tabular}

${ }^{*}$ The values are means \pm SD $(n=50)$. In each row the means with the same superscript letter are not significantly different $(P>0.05)$. Refer to the landmarks in Fig. 1 and Table 1 for the dimension numbers in Table 3.

volume typically results due to the approximate maintenance of the diploid ratio of nuclear to cytoplasmic volume. Despite increase cell size, triploid individuals are not, as a rule, larger than diploids. This appears to be due to a reduction in cell numbers in those tissues and organs containing larger cells (Benfey, 1999). This study result accord with these rule, and similar result reported at cherry salmon, Oncorhychus masou (Park \& Zhang, 1994).

Some of these fishes have spread widely in the country and established stable populations in natural environments. However, the distribution and ecology of these introduced fishes has rarely been studied. Correct discrimination of introduced species from the most similar native species may be the starting point of conservation of our environ- ment and native species. The morphometric method, developed and tested successfully for identification of three carp species, would be valuable progress for rapid assessment of freshwater fish community structure of Korea.

These results suggest that the classification of each species and classification between diploid and spontaneous triploid morphometrical parameters used in this study are useful indices of morphometrical status in the each species.

\section{ACKNOWLEDGMENTS}

This study funded by the National Institute of Fisheries Science. Comments from anonymous reviewers greatly improved the quality of this manuscript. We declare that 
all experiments in this study comply with the current laws of Korea (Ordinance of Agriculture, Food and Fisheries, No. 1 - the law regarding experimental animals, No. 9932) and the Ethical Guidelines of Korea Maritime and Ocean University, Korea.

\section{REFERENCES}

Benfey TJ (1999) The physiology and behavior of triploid fishes. Fish Sci 7:39-67.

Chun SK, Park SW, Jung YS (1983) Drug-resistant bacteria isolated from Nakdonggang river and Carp-ponds. Bull. Korean Fish Soc 16:17-24.

Currens KP, Sharpe CS, Hjort R, Schreck CB, Li HW (1989) Effect of different feeding regimes on the morphometrics of chinook salmon (Oncorhynchus tshawtscha) and rainbow trout (O. mykiss). Copeia 3:689-695.

Goo IB, Im JH, Gil HW, Lim SG, Park I-S (2015) Comparison of cell and nuclear size difference between diploid and induced triploid in marine medaka, Oryzias dancena. Dev Reprod 3:127-134.

Kim I-S (1997) Illustrated Encyclopedia of Fauna \& Flora of Korea, Vol. 37, Freshwater Fishes. Ministry of Education, Korea, pp. 156-509.

Lee CL, Kim IS (1990) A taxonomic revision of the family bagridae (Pisces, Siluriformes) from Korea. Korean J Ichthyol 2:117-137.

Lim SG, Han HK, Kang JH, Gil HW, Goo IB, Park I-S (2015) Cytogentic characteristics of Cyprinidae between diploid and spontaneous triploid in major river of Korea. Ichthyol Res (Submitted).

Nam MM, Yang HJ, Seo BK (1989) Morphologicla variation of the crucian carp, Carassius auratus (Linnaeus) from Yongnam area in Korea. Korean J Ichthyol 1:5463.

Park I-S, Gil HW, Oh JS, Choi HJ, Kim CH (2015) Comparative analysis of morphometric characteristics of Scorpaenidae and Gobioninae. Dev Reprod 2:85-96.
Park I-S, Im JH, Ryu DK, Nam YK, Kim DS (2001b) Effect of starvation on morphometric changes in Rhynchocypris oxycephalus (Sauvage and Dabry). J Appl Ichthyol 17:277-281.

Park I-S, Nam YK, Douglas SE, Johnson SC, Kim DS (2003) Genetic characterization, morphometrics and gonad development of induced interspecific hybrids between yellowtail flounder, Pleuronectes ferrugineus (Storer) and winter flounder, Pleuronectes americanus (Walbaum). Aquacult Res 34:389-396.

Park I-S, Woo SR, Song YC, Cho SH (2007) Effects of starvation on morphometric characteristics of olive flounder, Paralichthys olivaceus. Ichthyol Res 54:297-302.

Park I-S, Zhang CI (1994) Morphometrical differences between diploid and induced triploid cherry salmon, Oncorhynchus masou. Korean J Ichthyol 6:206-221.

Park I-S, Zhang CI, Lee YD (2001a) Sexual dimorphism in morphometric characteristics of cocktail wreasse. J Fish Biol 58:1746-1749.

Song KH, Jung JW, Koo HY, Kim W (2007) Development of species-specific molecular marker as a tool for discrimination between crucian carp gengorobuna (Carassius cuvieri) introduces from Japan and Korean native one (C. auatus). Korean J Limnol 40:143-148.

Strauss RE (1985) Evolutionary allometry and variation in body form in the South American catfish genus Corydoras (Callichthyidae). Syst Zool 34:381-396.

Strauss RE (1986) Naturla hybrids of the freshwater sculpins Cottus bairdi and Cottus cognatus (Pisces: Cottidae): electrophoretic and morphometric evidence. Amer Mid Nat 115:87-105.

Strauss RE, Bond CE (1990) Toxonomic methods, morphology. In: Schreck, C.B. and Moyle, P.B. (eds.), Methods for Fish Biology. Amer. Fish. Soc., Bethesda, Maryland, pp. 125-130.

Strauss RE, Bookstein FL (1982) The truss: body from reconstructions in morphometrics. Syst Zool 31:113-135. 